\title{
Whooping Cranes Photographed in the Aransas Refuge
}

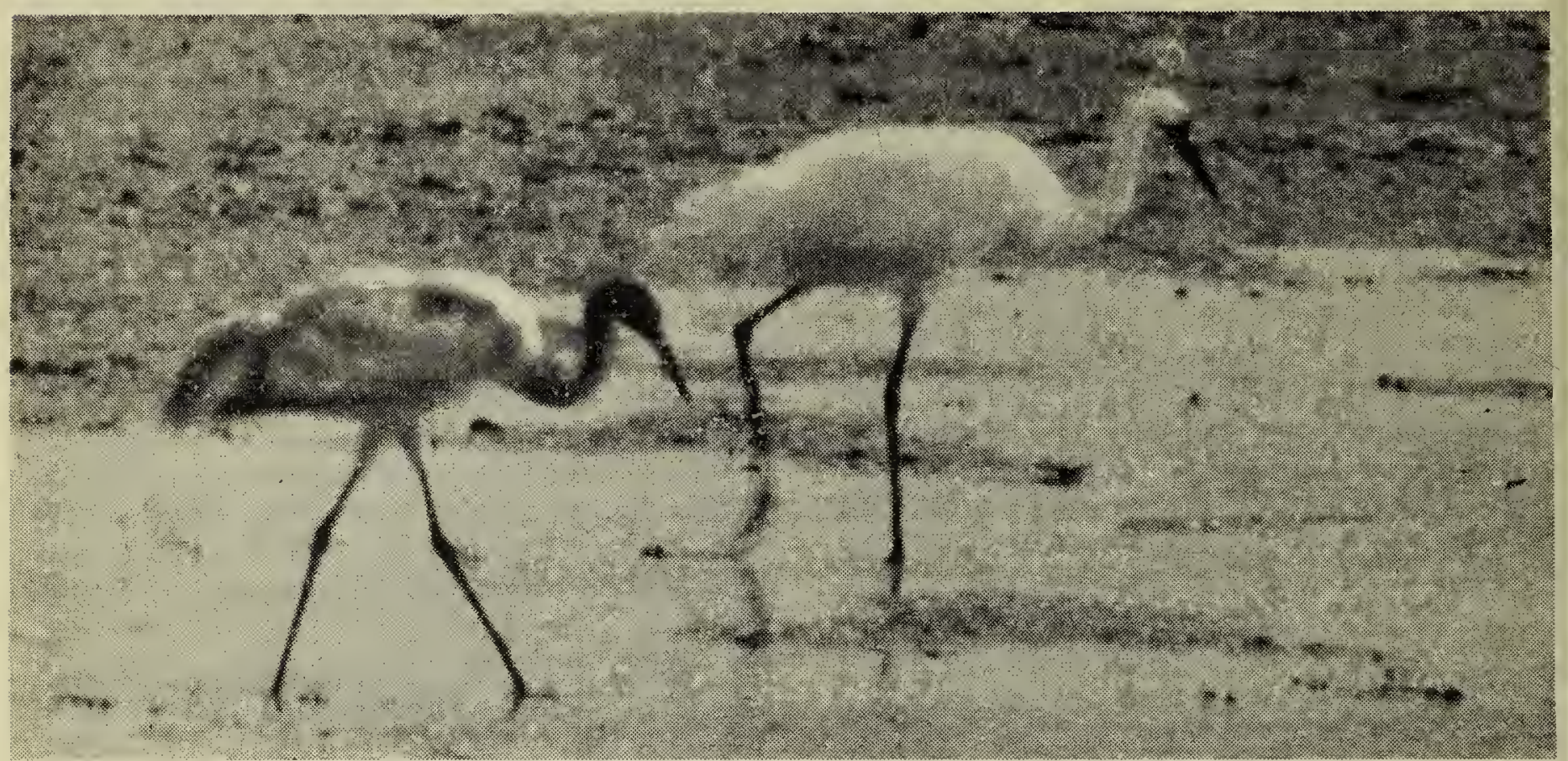

Photo by Horace Tucker

THE KIND OF PHOTOGRAPH YOU GET ONCE-IN-A-LIFETIME

Female Whroping Crane and young feeding in the Aransas National Wildife Refuge

A Great Picture! One of the Rarest You have Ever Seen! With this caption, the above picture of a female Whooping Crane and its young appeared in the Houston Press, December 7, 1956. Through the great kindness of the Press and the Press staff photographer Horace Tucker, we are able to print this rare photograph and the two on the following page to accompany the pictures of the Whooping Cranes taken by Fred Lahrman here in Saskatchewan when the birds were on their way to the Aransas Refuge.

It took a great deal of time and a great deal of special equipment to make these pictures. The story is told by a Press staff writer, Louis Blackburn - Horace Tucker and a companion cameraman, with the permission of the federal government, set up their camera gear among scrub oak and palmetto on the very edge of the swampy shores of Mustang Lake in the Aransas refuge. They waited patiently for Whooping Cranes to appear. Hour after quiet hour went by. Then ... Cautiously from the scrubby salt cedar stepped the proud family of three, the father picking his way slowly with long, graceful strides, the mother dipping her feet daintily into the mirrored face of the backwater as she swept gracefully from the shadows into the full light of the mellow sun. Junior followed, tripping lightly through the water on his long, awkward legs and shaking out his brown feathers

Only a few houns before, the Whooping Crane family, three of the last 24 members of their species, had dropped 20,000 feet out of the stratosphere to land at last in their winter home after a perilous journey on the high-flying jet stream from the Arctic Circle to the Gulf.

The tired birds sunned themselves lazily, unaware of the two shadows that moved slowly through the scant

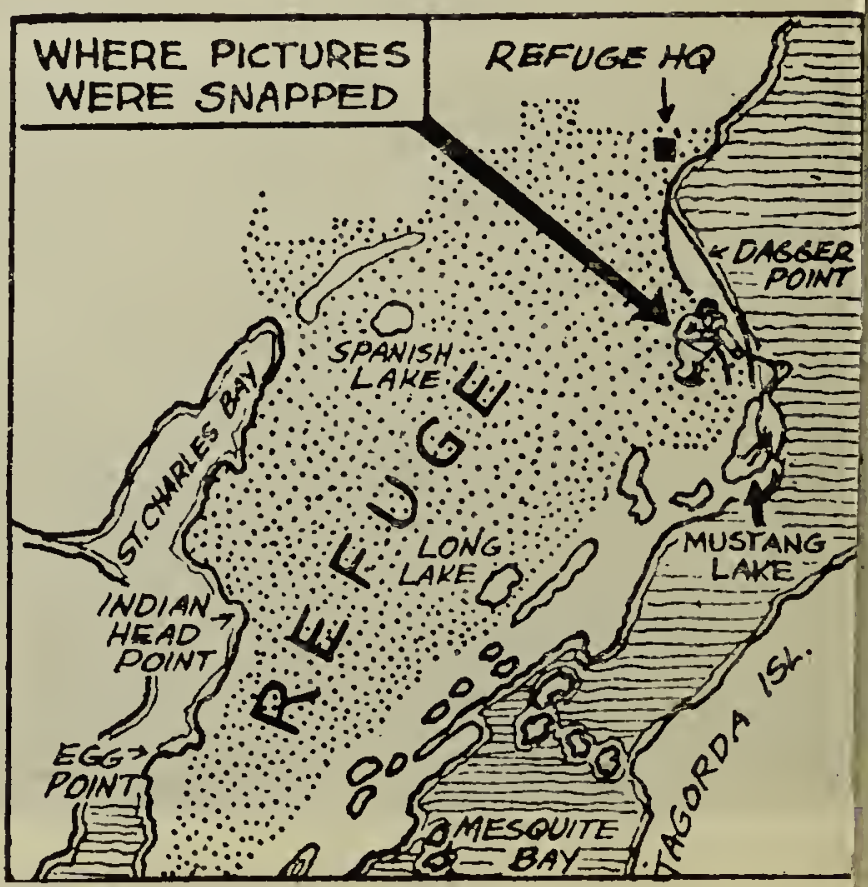


oliage of the swamp. The stalking hadows slowed to a dead stop and hovered ominously on a dying south vind. The deathly silence was proken by a shrill cry from the father crane... The deed was done. The quarry was in the bag. The camera-shy Whooping Cranes had been trapped at last in the lens of a newspaper photographer.

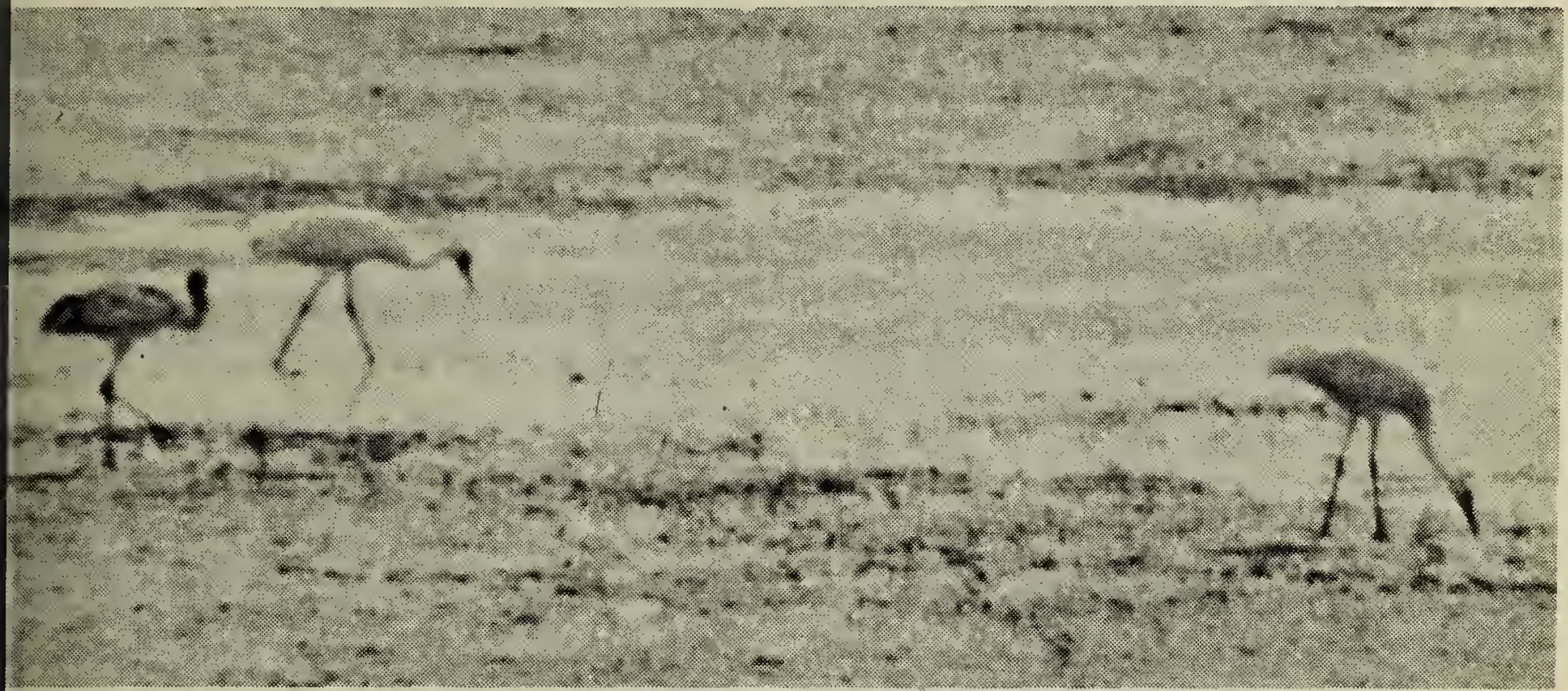

Photo by Horace Tucker THESE RARE WHOOPERS FLY TO ARANSAS EVERY WINTER FROM CANADA
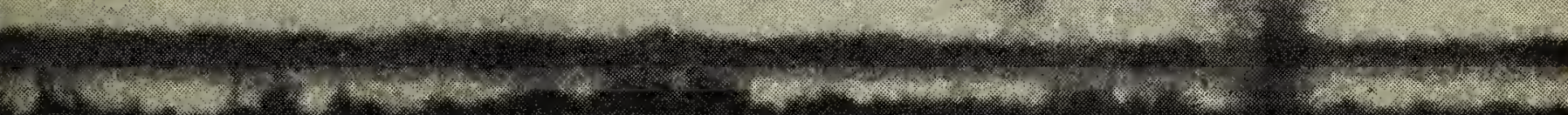